Glass made in a continuous glass-melting furnace is run into moulds as with iron castings. The only precaution that has to be taken is that the moulding material shall have as nearly as may be the same specific heat and the same conductivity for heat as glass. Various mixtures of materials that are easily obtainable and not costly are suitable, such as mixtures of powdered porcelain, glass pots, metal turnings and filings, and such minerals as heavy spar and magnetic iron ore. These are pulverised and mixed in certain proportions, and then moulded in the ordinary way. The glass being run into the mould, the mould and its contents are heated up together, and then cooled together, and, when cool, the mould is opened and the glass removed. Glass may thus be cast into forms which it would be impossible to produce otherwise. That glass may thus be manufactured of great homogeneity was proved by the clear ring of a large tuning-fork made of the material, and in the manner described. Mr. Siemens promises on a future occasion to bring this matter again before the Society of Arts, after the completion of the works which he is now erecting for the manufacture of glass according to the process last described. As regards the other processes, the manufacture has increased in six years from $600 l$. to $7000 \%$, and, considering the very cheap rate at which hard glass castings can be produced-viz. about $5 s, 6 d$. a hundredweight-Mr. Siemcns feels satisfied that a large business will be done, more particularly as they supply a want which is felt on all sides; and thinks that glass not being liable to oxidation, as soon as it could be depended upon as regards strength, it would be applied for purposes for which metals, stone, and porcelain have hitherto been used.

\section{THE PHYSIOLOGICAL LABORATORY AND OXFORD MEDICAL TEACHING}

$\left[\mathrm{W}^{\mathrm{B}}\right.$

$E$ regret to learn that another attempt is being made to suppress physiological teaching at Oxford. The not-over-scrupulous foes of scientific teaching and research have, we understand, distributed manifestoes by thousands all over the country. We hope, therefore, that the following statement will receive equally wide circulation. Scarcely any of the well-known men who have signed the statement are in any way connected with what is generally known as science ; certainly not one of them would have signed it had there been the least suspicion that in the Oxford Laboratory there would be any approach to cruelty :--]

A decree to provide for the expenditure of the department of Physiology will be submitted to Convocation on Tuesday, March io. The annual sum required for this purpose is $300 \%$., besides $200 \%$. for the salary of the Demonstrator of Histology.

The arrangements for the organisation of a complete system of instruction in the subjects of the first B.M. Examination and of the first and second I'rofessional Examinations of the Conjoint Board of the College of Physicians and of the College of Surgeons in London are in progress, and will soon be completed. The new Lecturer on Human Anatomy will very shortly be appointed, and the Physiological Laboratory will be complcted and ready for occupation by the end of the summer; so that before next October the University will be in a position to undertake the teaching of Human Anatomy and Physiology. The arrangements for teaching the other subjects in which instruction is required by medical students are also in progress.

As, in accordance with the recent resolution of the Colleges of Physicians and Surgeons, Candidates who have satisfied the Oxford Examiners in Anatomy, Physiology, and the other subjects of the first and second Professional Fxaminations, will be exempted from further examination in these subjects, Members of the University will in future be able to complete their first two years of medical study without leaving $\mathrm{Oxford}$.

The purpose for which the expenditure is required is instruction not research, and no experiments upon the living animal involving pain will be used for demonstration to students or instruction, with or without ancesthetics.

It is, however, intended by those who desire absolutely to prohibit such experiments in physiological inquiry, to oppose the decree for the maintenance of the laboratory. Energetic measures are being taken to this end. The rejection of the decree would involve fatal consequences as regards the above-mentioned scheme for the teaching of medical science. The University has already twice pronounced upon the issues now sought to be raised, by votes taken in unusually full Convocations on June 5 , 1883, and February 5, 1884. We, therefore, trust that you will be good enough to attend and vote in favour of the Decree on March 10 , at 2 p.m.

H. G. LITDELl, Dem of Christ Chureb.

J. FRANCK BRIGH', Master of University.

GEORGL C. BRODRICK, Warden of Merton.

J. P. LighTFooT, Rector of Exeter College.

DAVID B. MonRo, Provost of Oriel.

Johrn R. Magrath, Provost of Queen's.

J. E. SEWELL, Warden of New College.

W. W. MERRY, Rector of Lincoln.

W. R. ANson, Warden of All Souls.

E. H. CRADOCK, Principal of B.N.C.

T. FOWLLR, President of Corpus.

J. Precival, President of Trinity.

H D. HARper, Principal of Jesus College.

G. E. Thortey, Warden of Wadham.

EDWARD S. TAIBOT, Warden of Keble.

William InCE, Regius Professor of Divinity.

H. W. ACI.AND, Regius Professor of Medicine.

W. H. Fref.MANTLE, Fellow of Balliol College.

JOHN CONROY, Christ Church

AlfRED ROBINSON, Fellow of New College.

T. Herber't WARREN, Fellow of Magdalene College.

F. MAX MÚleER, Corpus Professor of Comparative I'hilology.

BARTHOLOMEW PRICE, Sedleian P'rofessor of Natural Philosophy.

HENRY NFi"TLESHIP, Corpus Professor of Latin.

JAMES LEGGE, Professor of Chinese.

J. EARLE, Professor of Anglo-Saxon.

John RHys, Professor of Celtic.

T. H. T. Hopkins, Fellow of Magdalen.

W. Lock, Fellow of Magdalen College, Sub-Warden of Keble Collegc

W. W. JACKSON, Fellow of Exeter, Censor of Non-Collegiate Students.

H. F. TozsR, Fellow and Tutor of Exeter.

A. G. BUTLER, Fellow and Tutor of Oriel.

AUBREY MOORF, Tutor of Keble and Magdalen.

RonerT L. OTTLEv, Student of Christ Church.

W. MARK BV, Reader in Indian Law, Fellow and Tutor of Balliol College, and Fellow of All Souls' College.

H. F. PelmaM, Exeter College.

\section{THE MAXIM GUN}

$\mathrm{M}^{\mathrm{R}}$ R. HIRAM STEVENS MAXIM, the well-known American engineer, has lately brought out a new form of a machine-gun, which is attracting a great deal of attention in military and naval circles. 1 his gun is a completely new departure. It takes the cartridges out of the box in which they were originally packed, puts them into the barrel, fires them, and expels the empty cartridges, using, for this purpose, energy derived from the recoil of the barrel. Of course it is necessary to put the first cartridge into the barrel by hand. When, however, this is done, and the trigger pulled, the gun will go on and fire as long as therc are any cartridges in the box. 